\title{
$>$ Macunaíma: diálogo com o romantismo a partir da paródia de Peri
}

\author{
> Macunaíma: a dialogue with the romanticism mouvement - \\ the Peri's parody
}

por Maria Júlia Pereira

Universidade Estadual Paulista Júlio de Mesquita Filho.

E-mail: majuper@gmail.com. ORCID: 0000-0001-7443-8775

\begin{abstract}
Resumo
Macunaíma: o herói sem nenhum caráter (1928), de Mário de Andrade, é o romancerapsódia que versa sobre a trajetória de um herói baseado nas lendas indígenas amazônicas e apresentado como autenticamente brasileiro. Tal romance insere-se na tradição de ruptura que marca o Modernismo. Dessa forma, a paródia se faz presente como intenção em diversas cenas da obra. Neste trabalho, a paródia será tratada enquanto deformação e transformação; ou imitação com distanciamento crítico da figura do herói romântico indianista idealizado, que a personagem Peri, de O Guarani (1857), de José de Alencar, encarna.
\end{abstract}

Palavras-chave: Macunaíma. Peri. Herói. Paródia.

\begin{abstract}
Macunaíma: o herói sem nenhum caráter (1928), by Mário de Andrade, is a novel-rhapsody about the trajectory of a hero based on Amazonian indigenous legends and presented as authentically Brazilian. This novel is part of the tradition of rupture that marks Modernism. Thus, the parody is presented as a purpose in many scenes of this work. In this article, the parody will be treated as deformation and transformation; or imitation with a critical distance from the figure of the idealized romantic Brazilian Indian hero, who is incarnated by the character Peri in O Guarani (1857), by José de Alencar.
\end{abstract}

Keywords: Macunaíma. Peri. Hero. Parody 


\section{Introdução}

Considerando a perspectiva crítica de Mário de Andrade em relação aos escritores românticos e a possível aproximação entre Modernismo e Romantismo, almeja-se discutir, no presente artigo, a paródia do herói romântico indianista idealizado a partir de Peri, de O Guarani (1857), de José de Alencar, contida na construção e na ação do herói modernista "sem nenhum caráter" Macunaíma - de Mário de Andrade.

É importante destacar que, no presente artigo, não se pretende abordar a totalidade da trajetória dos heróis mencionados, nem esgotar todas as possibilidades paródicas que Mário de Andrade delineou na obra e na personagem Macunaíma, mas, sim, tecer possíveis considerações sobre a paródia do herói indianista idealizado no que diz respeito à deformação e transformação a partir da comparação entre descrições e cenas do romance romântico e da rapsódia. Busca-se demonstrar e discutir uma possível relação entre os heróis romântico e modernista mediada pela paródia em dois vieses: o destrutivo e o construtivo. Nesse sentido, foram selecionadas cenas que dialogam entre si, como a dos rituais canibais dos aimorés e de Ceiuci, e as do abandono do ambiente primitivo por Peri e Macunaíma. Tais trechos abordam o caráter das personagens em questão e evidenciam a subversão (ou deformação) paródica efetuada por Macunaíma na condição de herói sem nenhum caráter. Além disso, na obra de Mário de Andrade a relação do nativo com a civilização é retomada e apresentada sob uma perspectiva crítica, (paródia de transformação), que se revela na conversão simbólica de Macunaíma ao tornar-se branco para adentrar a cidade, meio civilizatório e síntese do progresso técnico que marca distanciamento do primitivo.

Desse modo, tendo em vista a abordagem pretendida, é fundamental tratar, ainda que brevemente, da concepção de paródia e de sua relação com o Modernismo. Para isso, serão expostas e relacionadas as considerações sobre paródia de Gérard Genette (2006), Linda Hutcheon (1985) e Tiphaine Samoyault 
(2008). Mais especificamente, sobre a relação do Modernismo com a paródia dentro da tradição da ruptura, serão apontadas as observações de Octavio Paz (1984) e Silviano Santiago (1989). Portanto, do corpus deste trabalho foram selecionados trechos que evidenciam a paródia de Macunaíma em relação a Peri sob as duas perspectivas mencionadas: a da deformação, destruição ou do escárnio e a da imitação ou transformação com distanciamento crítico (uma espécie de paródia construtiva).

\section{A paródia em Macunaíma e o diálogo com o Romantismo}

Segundo Octavio $\mathrm{Paz}^{1}$, a "tradição da ruptura" é inaugurada pelo romantismo, pois o movimento romântico, por meio da rebelião contra a racionalidade iluminista e pela valorização do "corpo, de suas paixões e suas visões" ("erotismo, sonho, inspiração"), estabeleceu um discurso contra as regras vigentes no que dizia respeito à produção da arte e, sobretudo, da poesia. Partindo da expressão cunhada por Paz, Silviano Santiago ${ }^{2}$ assinala a existência de uma forte tendência de se analisar o Modernismo pelo viés de uma "tradição da ruptura". Nesse sentido, "nossa formação esteve sempre configurada por uma estética da ruptura, da quebra, por uma destruição consciente dos valores do passado", o que fez com que o discurso da paródia se tornasse "um dos mais privilegiados dentro do Modernismo". Assim, a tradição denominada "passadismo", principalmente pelos modernistas da década de 1920, sempre esteve presente no moderno - aqui entendido como a tradição moderna iniciada no Romantismo - e na "produção artística dos modernistas brasileiros".

O Modernismo no Brasil caracterizou-se pelo "apego construtivo à nossa civilização indígena de um lado e às civilizações africanas de outro". Os artistas do primeiro momento modernista propunham uma "revisão histórica" ${ }^{3}$, sendo

\footnotetext{
${ }^{1}$ Octavio Paz, Os filhos do barro, 1984, p. 133.

${ }^{2}$ Silviano Santiago, Nas malhas da letra, 1989, p. 94 a 96.

${ }^{3}$ Ibidem, p. 106.
} 
Oswald de Andrade um importante expoente dos princípios de tal revisão. Desse modo, "a emergência do discurso histórico no Modernismo visa a uma valorização do nacional em política e do primitivismo em arte". ${ }^{4}$ Essa valorização do nacional e do primitivismo é evidenciada nas obras de Tarsila do Amaral, de Oswald de Andrade e também de Mário de Andrade.

É importante ainda destacar que, para Silviano Santiago, a paródia busca sempre romper com a linha da tradição ao trazer uma perspectiva de ironização dos valores do passado, sendo concebida, dessa forma, como "uma ruptura, um escárnio com relação àquela estética que é dada como negativa"5. Enquanto a paródia se relaciona com a ruptura ridicularizando o passado, o pastiche diz respeito à imitação, à reverência - "o pastiche endossa o passado"6. O autor também compreende a paródia como um "procedimento retórico"7 que, ao ser repetido e reformulado, será reatualizado, criando-se, assim, uma tradição da ruptura marcada pela presença da "paródia da paródia".

No século XX, a paródia ganhou um novo significado, pois deixou de ser mero objeto de reavaliação de uma obra para se tornar "um dos modos maiores de construção formal e temática de textos", apresentando "uma função hermenêutica com implicações simultaneamente culturais e ideológicas" e constituindo, na arte, uma possibilidade importante de "autorreflexividade" (ou autorreferencialidade) e até mesmo uma espécie de "discurso interartístico". 9 Nessa perspectiva, Tiphaine Samoyault trata a paródia no contexto da autorreferencialidade literária, isto é, da intertextualidade, também denominada "memória da literatura"10. Assim, partindo do conceito de hipertextualidade de Genette $^{11}$ - toda relação que une um determinado texto (hipertexto) a outro texto

\footnotetext{
${ }^{4}$ Ibidem, p. 107.

${ }^{5}$ Ibidem, p. 107.

${ }^{6}$ Ibidem, p. 107.

${ }^{7}$ Ibidem, p. 107.

${ }^{8}$ Ibidem, p. 122.

${ }^{9}$ Linda Hutcheon, Uma teoria da paródia, 1985, p. 12 a 13.

10 Tiphaine Samoyault, Intertextualidade, 2008, p. 47 a 59.

${ }^{11}$ Gérard Genette, Palimpsestos: a literatura de segunda mão, 2006, p. 12.
} 
anterior (hipotexto) do qual ele deriva, de maneira distinta do comentário Samoyault aponta o pastiche e a paródia como "práticas intertextuais"12 caracterizadas por uma relação de derivação e mais dependentes da hipertextualidade do que da intertextualidade. A autora assinala ainda que, ao buscar uma definição etimológica da palavra paródia, Genette reforça a operação de derivação. Dessa forma:

A operação implica uma transformação (paródia) ou uma imitação (pastiche) do texto anterior que o hipertexto evoca de uma maneira ou de outra sem citá-lo diretamente, como é o caso do pastiche onde um estilo é imitado sem que o texto seja jamais citado. As duas principais formas de derivação são a paródia e o pastiche.

A paródia transforma uma obra precedente, seja para caricaturá-la, seja para reutilizá-la, transpondo-a. Mas qualquer que seja a transformação ou a deformação, ela exibe sempre um liame direto com a literatura existente ${ }^{13}$.

Em sentido semelhante, Linda Hutcheon assevera que, apesar de ser evidente na paródia moderna o intuito "do irônico e jocoso ao desdenhoso ridicularizador", a paródia é uma repetição com um distanciamento crítico, "que marca a diferença em vez da semelhança", o que nem sempre ocorre "às custas do texto parodiado"14. Ou seja, apesar da paródia se apresentar comumente como deformação do texto parodiado, ela pode também se apresentar como uma transformação desse texto a partir da ironia - da distância crítica - distinguindose dessa ideia de deformação ou destruição. Assim, Hutcheon encara a paródia como uma "imitação com diferença crítica" e entende que não há nada na paródia demandando a "inclusão de um conceito de ridículo, como existe, por exemplo, na piada, ou burla, de burlesco. A paródia é, pois, na sua irônica 'transcontextualização' e inversão, repetição com diferença"15, na qual está implícita uma distância crítica - marcada pela ironia - entre o texto parodiado e a obra que o incorpora. Tal ironia pode ser apenas bem humorada, ou depreciativa; criticamente construtiva ou destrutiva. "O prazer da ironia da paródia não provém

\footnotetext{
${ }^{12}$ Tiphaine Samoyault, Op. Cit., 2008, p. 52 a 53.

${ }^{13}$ Ibidem, p. 53.

${ }^{14}$ Linda Hutcheon, Op. Cit., 1985, p. 17.

${ }^{15}$ Ibidem, p. 48 a 52.
} 
do humor em particular, mas do grau de empenhamento do leitor no 'vai-vém' intertextual" ${ }^{16}$

Macunaíma: o herói sem nenhum caráter (1928) foi publicado no contexto do primeiro momento modernista, fruto de diversas pesquisas de Mário de Andrade. Dessa maneira, na perspectiva da tradição da ruptura, é evidente que, ao se considerar tal obra como paródia de livros românticos e indianistas de Alencar, como O Guarani (1857), conforme se pretende fazer neste trabalho, Macunaíma apresenta características de escárnio e deformação nítidas em relação à obra parodiada. No entanto, a aproximação entre Macunaíma e Peri não se dá apenas no nível paródico de escárnio, mas também pela crítica irônica, isto é, o diálogo entre o herói de Mário de Andrade e o herói de José de Alencar é desenvolvido por meio da referência intertextual. Assim, a concepção de paródia enquanto distanciamento crítico também é fundamental para evidenciar a relação entre as personagens Macunaíma e Peri. Isso pode ser inferido na leitura do artigo Curemos Peri - escrito como resposta ao texto Matemos Peri, de Menotti Del Picchia - em que Andrade, de certo modo, reconhece a contribuição romântica para a literatura na busca de se compreender a formação da identidade nacional:

Primeiramente há uma certa confusão no seu artigo. $\mathrm{O}$ amigo ora fala do Peri homem - solidão ambulante dos matagais, ora do Peri símbolo, múltiplo fantasma construído de ossos legítimos e de mortalhas falsas. Daquele diz que é "vadio, estúpido, inútil", que tem "a tez acapetada, nariz chato, higiene discutível", acrescentando saber disso tudo pelos livros sérios que leu. A estes poderia eu contrapor outros sérios livros onde a verdade não é a mesma. [...] O meu Roquette Pinto, em primeira edição, pelo seu descompassado volume não tem lugar nos raios da estante e aqui está numa gaveta de secretária. Se o tivesse lido, caríssimo Hélios, lá encontraria utilíssimas informações em estilo ameno e grácil. Lá acharia, além de observações próprias, as de outros etnógrafos que desdizem do seu acerto. [...] Mas você, na sua loira visão de poeta, chega a negar até que os índios tenham contribuído para a formação da nossa sub-raça, ou das nossas sub-raças!...

Sinto-o mais sonhador e romantizado que esse estudioso e grande Gonçalves Dias, autor de ensaios interessantíssimos e sérios, alcunhado com tanta impropriedade, pelo autor de "Lais" de "ridículo". Ridículo porque [sic]? Porque vives as tendências da sua época? Porque sonhou,

${ }^{16}$ Ibidem, p.48 - 52. 
cantou, chorou, transplantando-os genialmente para o nosso meio os mesmos sonhos, cantares e lágrimas dos vates de seu tempo? Não seria melhor pensar como Émile Rayard, que as obras-primas de todas as eras se equivalem, não só pelo que possuem de representativo e de histórico, mas pelo que são como ânsias igualmente valorosos nesta insana porfia em que penamos, todos nós, poetas crianças, em procura desse passarinho azul, que é a beleza vária e mutável? Amigo, desassombrado lhe conto que no dia em que li o seu escrito lucrei horas de glorioso lazer relendo I-JucaPirama e os Timbiras. I-Juca-Pirama, embora Sarolea o desconheça, é mais belo que os Natchez, mais nobre que Rolla, mais forte que Hernani... ${ }^{17}$

Ao mencionar que Gonçalves Dias não merece a alcunha de ridículo assinalada por Picchia, pois, afinal, o poeta romântico viveu as tendências de seu tempo e trouxe ideias que reverberaram no Modernismo, Mário valoriza o legado da tradição romântica enquanto primeiro passo para um projeto estético genuinamente nacional. Nesse sentido, Telê Porto Ancona Lopezafirma que a primeira versão definitiva do romance Macunaíma continha dedicatória não apenas a Paulo Prado - como ficou após a obra ser editada - mas também a José de Alencar: "pai-de-vivo que brilha no vasto campo do céu"18. Assim, apesar de ter sido retirada a dedicatória a Alencar, resta evidente que o autor de O Guarani seria "pai-do-vivo Mário de Andrade, que o consagrou à perenidade do cosmos"19. Dessa forma, o modernista reconheceu "a importância do papel representado pelo escritor romântico"20 no que diz respeito à busca por elementos de origem nacional e "à afirmação da personagem do romance como o anseio de retratar o brasileiro com autenticidade através do indianismo"21.

Romantismo e Modernismo foram dois movimentos artísticos de bases nacionalistas, o primeiro pelo viés da idealização e o segundo pelo nacionalismo crítico. Nesse sentido, ambos apresentam obras literárias caracterizadas por histórias que versam sobre o indígena e sua condição de nativo da terra. Tratase, pois, de movimentos com temática comum na busca pela consolidação de uma identidade brasileira, apesar das abordagens serem muito distintas. Com efeito, conforme expõe Cavalcanti Proença: "em Alencar falam os cronistas, em Mário

\footnotetext{
${ }^{17}$ Mário de Andrade, Curemos Peri, 2012, p. 112 a 113.

${ }^{18}$ Telê Porto Ancona Lopez, Macunaíma: a margem e o texto, 1974, p. 75.

${ }^{19}$ Ibidem, p. 75.

${ }^{20}$ Ibidem, p. 75.

${ }^{21}$ Ibidem, p. 75.
} 
os etnógrafos"22. Portanto, considerando que Mário, em sua busca pela revitalização do ameríndio, "não reconhece indianismo em Macunaíma"23, é possível inferir que a paródia do herói Peri em Macunaíma faz dois aspectos distintos coexistirem: a deformação da personagem em sua caracterização e o distanciamento crítico irônico - a transformação no que diz respeito à maneira alencariana de valorizar o primitivo e o nacional - o que será evidenciado no tópico a seguir.

\section{O herói Macunaíma: deformação e transformação paródica do herói romântico Peri}

Em O Guarani, Peri aparece na Parte Primeira, capítulo IV, caçando para satisfazer a vontade de sua senhora Ceci (Cecília), que desejava ver de perto uma onça viva. $\mathrm{O}$ indígena da tribo dos guaranis, de alta estatura e pele brilhante da cor do cobre é caracterizado como um sujeito extremamente habilidoso e incansável: "tinha as mãos delicadas; a perna ágil e nervosa", era "firme no andar e veloz na corrida"24. Além da impressionante aparência e agilidade do herói, o narrador apresenta seu caráter como o atributo mais admirável por meio da fala da personagem Dom Antônio de Mariz, o fidalgo português:

- Vede vós, meu pai, respondeu Cecília enxugando as lágrimas que lhe saltavam dos olhos; conversava quinta-feira com Isabel, que tem grande medo de onças, e brincando, disse-lhe que desejava ver uma viva!...

- E Peri a foi buscar para satisfazer o teu desejo, replicou o fidalgo rindo. Não há que admirar. Outras tem ele feito.

- Porém, meu pai, isto é coisa que se faça! A onça deve tê-lo morto.

- Não vos assusteis, D. Cecília; ele saberá defender-se.

- E vós, Sr. Álvaro, por que não o ajudastes a defender-se? Disse a moça sentida.

\footnotetext{
${ }^{22}$ Manuel Cavalcanti Proença, Roteiro de Macunaíma, 1969, p. 44.

${ }^{23}$ Ibidem, p. 44.

${ }^{24}$ José de Alencar, O Guarani, 1982, p. 34
} 
- Oh! Se vísseis a raiva com que ficou por querermos atirar sobre o animal! E o moço contou parte da cena passada na floresta.

- Não há dúvida, disse D. Antônio de Mariz, na sua cega dedicação por Cecília quis fazer-lhe a vontade com risco de vida. É para mim uma das coisas mais admiráveis que tenho visto nesta terra, o caráter desse índio. Desde o primeiro dia que aqui entrou, salvando minha filha, a sua vida tem sido um só ato de abnegação e heroísmo. Crede-me Álvaro, é um cavalheiro português no corpo de um selvagem. ${ }^{25}$

Uma das maiores contribuições românticas para a literatura brasileira é o "herói indígena com significado de Brasil"26, sendo o índio a principal razão pela busca da identidade nacional por parte da literatura indianista. Todavia, o herói apresentado por José de Alencar resulta de "uma concepção ética de homem branco, europeizado e civilizado"27, distanciando-se da autenticidade do comportamento brasileiro - como resta evidenciado no trecho acima - Peri é um nativo com caráter português: seu comportamento, sua altivez, sua dedicação e adoração por Cecília evocam a nobreza e os valores dos fidalgos medievais, inclusive a moral cristã, tendo em vista que o indígena nutre uma devoção religiosa por Cecília, vendo nela a imagem de Nossa Senhora. Assim, a personagem Peri é construída a partir desse caráter firme, rígido, que consolida uma identidade nacional: o índio enquanto matriz social e o branco como parâmetro comportamental na lógica civilizadora.

Macunaíma, por sua vez, é "o herói sem nenhum caráter", e, propriamente por essa razão, é "o herói de nossa gente", "preto retinto", filho da tribo dos tapanhumas, que demorou mais de seis anos para começar a falar e vivia exclamando "ai, que preguiça!"28. Com o aparecimento do protagonista a obra "estruge", desde seu início, "num carnaval de dicas, tiradas, disparates, gozações, sátiras, paródia"29. Dessa forma, o protagonista delineado por Mário exprime uma nova compreensão da identidade nacional: a falta de caráter tem relação com a

\footnotetext{
${ }^{25}$ Ibidem, p. 34, destaque nosso.

${ }^{26}$ Telê Porto Ancona Lopez, Op. Cit., 1974, p. 76.

${ }^{27}$ Ibidem, p. 76.

${ }^{28}$ Mário de Andrade, Macunaíma: o herói sem nenhum caráter, In: LOPEZ, Telê Porto Ancona (coord.). Macunaíma: o herói sem nenhum caráter - edição crítica, 1988, p. 5.

${ }^{29}$ Darcy Ribeiro, "Liminar - Macunaíma", In Telê Porto Ancona Lopez (coord.), Op. Cit., 1988, p. XVIII.
} 
ausência de uma identidade formada, completa e acabada. Nessa perspectiva, Telê Ancona Lopezassevera que Mário de Andrade inferiu a necessidade de se configurar uma nova concepção do "homem nacional" e do primitivismo, pois a idealização romântica indianista não representava inteiramente o Brasil, isto é, "faltava alguém que simbolizasse o comportamento incaracterístico do povo brasileiro e o lançasse num todo sulamericano"30.

Em O Guarani, no capítulo XIII (Combate), da Terceira Parte, Peri é capturado pelos aimorés, que pretendem comê-lo em um ritual guerreiro. Uma das cenas do romance Macunaíma dialoga com esse capítulo de Alencar e revela a deformação e transformação paródica do herói: no capítulo XI, denominado $A$ velha Ceiuci, a personagem de Ceiuci, mulher do gigante Piaimã (Venceslau Pietro Pietra), quer comer o protagonista:

Não vá, herói, que você topa com a velha Ceiuci mulher do gigante. Te come, heim!

- Não tem inferno pra quem já navegou no Cachoeira! que Macunaíma exclamou. E partiu. Nem bem lançou a linha de cima dum mutá que veio vindo a velha Ceiuci pescando de tarrafa. A caapora viu a sombra de Macunaíma refletida n'água jogou depressa a tarrafa e só pescou sombra. O herói nem não achou graça porque estava tremendo de medo, vai, pra agradecer falou assim:

- Bom-dia, minha vó. A velha virou a cara pro alto e descobriu Macunaíma em riba do mutá.

- Vem cá, meu neto.

- Não vou lá não.

- Pois então mando marimbondos. Fez. Macunaíma arrancou um molho de pataqueira e matou os marimbondos.

- Desce, meu neto, que sinão mando novatas! Fez. As formigas novatas ferraram em Macunaíma e ele caiu n'água. Então a velha tarrafeou, envolveu o herói nas malhas e foi pra casa. Lá chegada pôs o embrulho na sala-de-visitas que tinha um abajur encarnado e foi chamar a filha mais velha que era bem habilidosa, pras duas comerem o pato que ela caçara. E o pato era Macunaíma o herói. Porém a filhona estava muito ocupada porque era mesmo habilidosa e a velha pra adiantar serviço foi fazer fogo. A caapora possuía duas filhas e a mais nova que não era nada habilidosa e só sabia suspirar, enxergando a velha fazer fogo, imaginou: "Mãe quando

${ }^{30}$ Telê Porto Ancona Lopez, Op. Cit., 1974, p. 79 a 80. 
vem da pescaria conta logo o que pescou, hoje não. Vou ver." Desenrolou a tarrafa e saiu dela um moço bem do gosto. O herói falou:

- Me esconde!

Então a moça que estava mui bondosa porque vivia desocupada desde tempo, levou Macunaíma pro quarto e brincaram. Agora estão se rindo um pro outro ${ }^{31}$.

Ao esquentar o fogo e dar falta do pato que pretendia comer, Ceiuci vai até o quarto da filha mais nova:

- Minha filhinha mais nova, entrega já meu pato que sinão enxoto você da casa minha pra todo o sempre!

A moça ficou com medo e mandou Macunaíma atirar vinte mil réis por debaixo da porta para ver si contentava a gulosa. Macunaíma de medo já atirou cem que viraram em muitas perdizes lagostas robalos vidros-deperfume e caviar ${ }^{32}$.

Além de pedir ajuda a filha mais nova de Ceiuci e ter relações sexuais com ela, Macunaíma, assumindo todo o medo que sentia, deixa de enfrentar a inimiga e dá início a uma fuga marcada por sua esperteza, pois consegue despistar a mulher do gigante. ${ }^{33}$ Em postura oposta, Peri, a quem foi oferecida, em meio ao rito canibal, a virgem filha do cacique dos aimorés para ser desposada antes da morte do herói, envenena-se e entrega-se ao inimigo por vontade própria, desejando enfrentá-lo e derrotá-lo como prova de seu autossacrifício por Cecília. Assim, o herói romântico não só se recusa castamente a ter qualquer relação com a virgem, como também dispensa a ajuda que ela lhe oferece para fugir dali: "tu és livre. Partamos! [...] Peri compreendera o movimento da índia, porém não fez o menor movimento de segui-la"34.

A construção da personagem Macunaíma evidencia uma deformação do herói Peri: sem caráter e sempre com preguiça, opõe-se ao indígena de caráter nobre e incansável, sempre disposto a lutar e até morrer por Cecília - causa de sua ação na história. Todavia, em Macunaíma também resta demonstrada a

\footnotetext{
${ }^{31}$ Mário de Andrade, Op. Cit., p. 105 a 106.

32 Ibidem, p. 106.

${ }^{33}$ Ibidem, p. 106 a 109.

${ }^{34}$ José de Alencar, Op. Cit., p. 167 a 174.
} 
transformação por meio de uma ironia que esboça o herói e suas ações. Nele há referência a Peri com certo distanciamento crítico, reproduzindo cenas do romance romântico não para a elaboração de uma crítica destrutiva, mas, sim, para configurar a autenticidade do herói e de seu agir incaracterístico, propriamente brasileiro, o que revaloriza o primitivo e o nacional abordados na obra romântica a partir de uma nova leitura. Com efeito, Macunaíma utiliza-se do ardil e da esperteza para se livrar de seus inimigos e sente medo, diferentemente de Peri, cujo caráter o faz comportar-se bravamente diante do inimigo e cuja coragem o impede de fugir. A devoção religiosa de Peri por Cecília engendra seu autossacrifício e sua castidade, outro aspecto subvertido pelo herói sem nenhum caráter, que sempre cede aos impulsos sexuais.

A personagem Macunaíma é, nesse sentido, delineada social e psiquicamente a partir de uma nova perspectiva do nacional: a identidade indefinida que resulta na ausência de caráter e a interação conturbada com a natureza e o ambiente urbano - que se trata de uma consequência característica da civilização - parodiam Peri, o herói romântico idealizado que retrata uma união do étnico local com a tradição europeia. Por esse ângulo, Alfredo Bosi afirma que a dificuldade de Mário em "definir a identidade simbólica do herói em termos de caráter brasileiro, vem do cruzamento de perspectivas que enforma a rapsódia"35. Isto é, a figura de Macunaíma é composta pelos dois pontos de vista que coexistem no autor: tanto pelo "'moderno', 'racional' e 'civilizado'", quanto pelo "'primitivo', 'arcaico' e 'mitopoético"'36.

Segundo Telê Ancona Lopez, Mário apoia a construção de Macunaíma em uma lenda indígena a partir de seu contato com a obra etnográfica de KochGrünberg: Mitos e lendas dos índios taulipang e arecuná, volume segundo de Vom Roroima zum Orinoco. ${ }^{37}$ Da mesma forma, Bosi sustenta que, sendo Macunaíma construído à maneira "dos heróis da mitologia amazônica", também é acionado

\footnotetext{
${ }^{35}$ Alfredo Bosi, Situação de Macunaíma, 1988, p. 179.

${ }^{36}$ Ibidem, p. 179.

${ }^{37}$ Telê Ancona Lopez, Op. Cit., 1974, p. 27.
} 
de forma imediata "pelos estímulos do prazer ou do medo"38, o que evidencia uma completa ruptura em relação ao agir do herói indianista. Nessa perspectiva, para o autor de Macunaíma, Peri, apesar de ser um lídimo tema nacional, não chega a configurar propriamente um herói brasileiro ${ }^{39}$, portando um significado de caráter ainda fundamentalmente atrelado à tradição europeia.

Outro aspecto paródico a ser mencionado se dá na relação estabelecida por Macunaíma com a cidade, ambiente urbano de progresso e fruto do projeto civilizatório europeu. De certo modo, é possível inferir que o elo do herói com o ambiente urbano está relacionado à própria civilização, isto é, às idéias de progresso, modernidade e racionalidade. No capítulo V, Piaimã, o herói, após seu amor primeiro $\mathrm{Ci}$, mãe do mato, reintegrar-se ao cosmos como estrela - a Beta do Centauro - sai da natureza para chegar à cidade de São Paulo. No entanto, pouco antes disso, o herói passa por uma importante transformação que se reflete, na narrativa, como um rito necessário para concretizar sua passagem para o meio urbano:

\begin{abstract}
Uma feita a Sol cobrira os três manos duma escaminha de suor e Macunaíma se lembrou de tomar banho. Porém no rio era impossível por causa das piranhas tão vorazes que de quando em quando na luta pra pegar um naco de irmã espedaçada, pulavam aos cachos para fora d'água metro e mais. Então Macunaíma enxergou numa lapa bem no meio do rio uma cova cheia d'água. $\mathrm{E}$ a cova era que nem a marca de um pé gigante. Abicaram. O herói, depois de muitos gritos por causa do frio da água entrou na cova e se lavou inteirinho. Mas a água era encantada porque aquele buraco na lapa era marca do pezão do Sumé, do tempo em que andava pregando o evangelho de Jesus pra indiada brasileira. Quando o herói saiu do banho estava branco louro, de olhos azuizinhos, água lavara o pretume dele. E ninguém não seria capaz mais de indicar nele um filho da tribo retinta dos Tapanhumas.
\end{abstract}

Nem bem Jiguê percebeu o milagre, se atirou na marca do pezão do Sumé. Porém a água já estava muito suja da negrura do herói e por mais que Jiguê esfregasse feito maluco atirando água para todos os lados só conseguiu ficar da cor do bronze novo.

Macunaíma teve dó e consolou:

\footnotetext{
${ }^{38}$ Alfredo Bosi, Op. Cit., 1988, p. 178-179.

${ }^{39}$ Telê Ancona Lopez, Op. Cit., 1974, p. 77.
} 
- Olhe, mano Jiguê, branco você ficou não, porém pretume foi-se e antes fanhoso que sem nariz.

Maanape então é que foi se lavar, mas Jiguê esborrifara toda a água encantada pra fora da cova. Tinha só um bocado lá no fundo e Maanape conseguiu molhar só a palma dos pés e das mãos. Por isso ficou negro bem filho da tribo dos Tapanhumas. Só que as palmas das mãos e dos pés dele são vermelhas por terem se limpado na água santa. Macunaíma teve dó e consolou:

- Não se avexe, mano Maanape, não se avexe não, mais sofreu nosso tio Judas!

E estava lindíssima na Sol da lapa os três manos um louro um vermelho outro negro, de pé bem erguidos e nus. Todos os seres do mato espiavam assombrados. $\mathrm{O}$ jacarèuna o jacarètinga, o jacaré-açu o jacaré-ururau de papo amarelo, todos esses jacarés botaram os olhos de rochedo pra fora d'água. Nos ramos das igàzeiras das aningas das mamoranas das embaúbas dos catauaris de beira-rio o macaco-prego o macaco-de-cheiro o guariba o bugio o cuatá o barrigudo o coxiú o cairara, todos os quarenta macacos do Brasil, todos, espiavam babando de inveja. E os sabiás,o sabiàcia o sabiàpoca o sabiàúna o sabiàpiranga o sabiàgonga que quando come não me dá, o sabiá-barranco o sabiátropeiro o sabiá-laranjeira o sabiá-gute todos esses ficaram pasmos e esqueceram de acabar o trinado, vozeando vozeando com eloquência. Macunaíma teve ódio. Botou as mãos nas ancas e gritou pra natureza:

- Nunca viu não!

Então os seres naturais debandaram vivendo e os três manos seguiram caminho outra vez.

Porém entrando nas terras do igarapé Tietê adonde o burbon vogava e a moeda tradicional não era mais cacau, em vez, chamava arame contos contecos milreis borós tostão duzentorréis quinhentorreis, cinqüenta paus, noventa bagarotes, e pelegas cobres xenxéns caraminguás selos bicos-de-coruja massuni bolada calcáreo gimbra siridó bicha e pataracos, assim, adonde até liga pra meia ninguém comprava nem por vinte mil cacaus. Macunaíma ficou muito contrariado. Ter de trabucar, ele, herói... Murmurou desolado:

- Ai! que preguiça!...

Resolveu abandonar a empresa, voltando prós pagos de que era imperador. Porém Maanape falou assim:

- Deixa de ser aruá, mano! Por morrer um carangueijo o mangue não bota luto! que diacho! desanima não que arranjo as coisas! Quando chegaram em São Paulo, ensacou um pouco do tesouro pra comerem e barganhando o resto na Bolsa apurou perto de oitenta contos de réis. Maanape era feiticeiro. Oitenta contos não valia muito mas o herói refletiu bem e falou prós manos:

- Paciência. A gente se arruma com isso mesmo, quem quer cavalo sem tacha anda de a-pé... Com esses cobres é que Macunaíma viveu. E foi numa 
boca-da-noite fria que os manos toparam com a cidade macota de São Paulo esparramada a beira-rio do igarapé Tietê. Primeiro foi a gritaria da papagaiada imperial se despedindo do herói. E lá se foi o bando sarapintado volvendo pros matos do norte ${ }^{40}$.

Uma leitura mais imediata do trecho acima infere uma referência ao que Marilena Chauídenomina "mito fundador": a ideia de que o povo brasileiro seja formado "pela mistura de três raças valorosas" - o indígena, o negro e o branco. Todavia, para a abordagem do aspecto paródico é importante destacar que a água encantada se apresenta como elemento místico da religiosidade cristã, pois há referência expressa à missão jesuítica de espalhar o evangelho entre os nativos "pregando o evangelho de Jesus pra indiada brasileira"41. A aculturação indígena, sobretudo pelo viés religioso, é parte essencial do projeto civilizatório europeu. Ao se banhar na mencionada água, Macunaíma torna-se branco. E somente após essa transformação simbólica o herói deixa a natureza, seu lugar de origem, para chegar à cidade - esse novo espaço regido pela civilização e pelo progresso tecnológico - onde o herói só adentra inteiramente após batizar-se nessa água mística incorporando etnicamente a herança europeia. Assim, a cidade não somente incorpora Macunaíma, mas, antes, é por ele incorporada, havendo uma relação simbiótica entre a personagem e o espaço de modo a restar inviabilizada qualquer possibilidade de estranhamento entre ambos. Nesse sentido, o herói, inicialmente contrariado por ter que trabucar, logo reflete e decide permanecer no local.

Dessa maneira, tem-se uma paródia por distanciamento crítico em relação ao herói romântico Peri, que também abandona a natureza e suas origens, pois deixa sua tribo: "Peri só ama o que a senhora ama; porque só ama a senhora neste mundo: por ela deixou sua mãe, seus irmãos e a terra onde nasceu" ${ }^{42}$. A presença portuguesa e sua intenção colonizadora alteram completamente a relação de Peri com o espaço e com suas próprias raízes, pois o herói romântico, em sua conversão, passando a adorar Cecília como a imagem da Virgem Santa (Nossa

\footnotetext{
${ }^{40}$ Mário de Andrade, Op. Cit., 1988, p. 37 a 39.

${ }^{41}$ Marilena Chauí, Brasil: mito fundador e sociedade autoritária, 2000, p. 6 a 9.

42 José de Alencar, Op. Cit., 1982, p. 89.
} 
Senhora), abandona o que lhe era culturalmente característico e incorpora a religiosidade cristã e a tradição europeia para adentrar o ambiente civilizado, ou seja, para poder frequentar a casa de D. Antônio de Mariz, e, assim, manter sua relação de devoção com Ceci.

Destarte, resta evidenciada a intertextualidade paródica entre os heróis modernista e romântico, visto que Macunaíma parodia Peri não apenas por meio da falta de caráter próprio - em nítida deformação quanto ao caráter nobre do herói indianista associado ao fidalgo europeu - mas também retomando com ironia, por meio da imitação com diferença crítica, a transformação comportamental do indígena após a conversão resultante do contato com o branco. Logo, a paródia da personagem Peri encarnada pelo herói Macunaíma se dá no nível da deformação (escárnio) e no da ironia, isto é, da crítica construtiva na releitura do primitivismo - o indígena concebido socialmente a partir do olhar do etnógrafo - por meio da qual Mário de Andrade demonstra por que Peri, apesar dos esforços de Alencar, não configura um genuíno herói brasileiro.

\section{Considerações finais}

A estreita relação entre paródia e intertextualidade é estabelecida na medida em que a paródia é uma forma de tecer o intertexto. Assim, o Modernismo, especialmente em seu primeiro momento mais diretamente ligado ao viés da tradição da ruptura, assumiu uma postura apta a rescindir com toda a tradição literária até então consolidada, adotando a paródia como um importante elemento para concretizar literariamente tal rescisão, conforme é possível observar nas obras de diversos autores de tal momento, dentre eles, Mário de Andrade. Nesse sentido, é possível examinar em Macunaíma: o herói sem nenhum caráter a intenção paródica em diferentes níveis e vieses. A título de exemplo pode-se mencionar a rapsódia como escárnio em relação ao próprio romance (à forma romanesca) ou as cartas icamiabas parodiando o estilo dos cronistas, cujas obras são um importante ponto de partida dos escritores românticos que buscam 
compreender a formação da identidade do Brasil. Todavia, este trabalho centrouse na paródia do herói romântico idealizado, buscando demonstrar como ela se dá em dois aspectos: um de crítica destrutiva, compreendido como deformação, e outro de crítica irônica construtiva, denominado transformação.

Portanto, a análise proposta no presente artigo pretendeu inferir como a paródia do herói romântico indianista - Peri - é engendrada, na obra de Mário de Andrade, por meio da intertextualidade como deformação e distanciamento crítico a partir do protagonista da história, que é proposto pelo modernista como o autêntico "herói de nossa gente". Mediante tal proposta, o autor assinala uma releitura do primitivismo e da busca romântica por uma identidade nacional que destrói a perspectiva idealizada do índio por meio do escárnio, ao mesmo tempo em que valoriza a contribuição romântica para a literatura nacional por meio da crítica irônica construtiva.

\section{Referências}

ALENCAR, José de. O Guarani. São Paulo: Ática, 1982.

ANDRADE, Mário. Macunaíma: o herói sem nenhum caráter. In: LOPEZ, Telê Porto Ancona. (coord.). Macunaíma: o herói sem nenhum caráter - edição crítica. Florianópolis: UFSC, 1988.

ANDRADE, Mário. Curemos Peri. Em: Gazeta. São Paulo, 31 de janeiro de 1921. Original disponível no Arquivo Mário de Andrade do Instituto Nacional de Estudos Brasileiros da Universidade de São Paulo. Acesso à transcrição em: ALVIM, Fernando José da Silva. Mário de Andrade e o romantismo brasileiro: tradição, imaginário e consciência histórica nacional. 2012. Dissertação (Mestrado em Letras). Disponível em:

$<$ http://www.teses.usp.br/teses/disponiveis/8/8149/tde-16082013104501/en.php>. Acesso em: 02 jul. 2018. 
BOSI, Alfredo. Situação de Macunaíma. In: LOPEZ, Telê Porto Ancona. (coord.). Macunaíma: o herói sem nenhum caráter. Florianópolis: UFSC, 1988.

CHAUÍ, Marilena. Brasil: mito fundador e sociedade autoritária. São Paulo: Fundação Perseu Abramo, 2000.

RIBEIRO, Darcy. "Liminar - Macunaíma". In: LOPEZ, Telê Porto Ancona (coord.). Macunaíma: o herói sem nenhum caráter - edição crítica. Florianópolis: UFSC, 1988.

GENETTE, Gérard. Palimpsestos: a literatura de segunda mão. Belo Horizonte: Faculdade de Letras, 2006.

HUTCHEON, Linda. Uma teoria da paródia. Tradução: Teresa Louro Pérez. Lisboa: Edições 70, 1985.

LOPEZ, Telê Porto Ancona. Macunaíma: a margem e o texto. São Paulo: Hucitec, 1974.

PAZ, Octavio. Os Filhos do Barro. Rio de Janeiro: Nova Fronteira, 1984.

PROENÇA, Manuel Cavalcanti. Roteiro de Macunaíma. Rio de Janeiro:

Civilização Brasileira, 1969.

SAMOYAULT, Tiphaine. Intertextualidade. Tradução: Sandra Nitrini. São Paulo: Hucitec, 2008.

SANTIAGO, Silviano. Nas malhas da letra. São Paulo: Companhia das Letras, 1989.

Referência para citação deste artigo PEREIRA, Maria. Macunaíma: diálogo com o romantismo a partir da paródia de Peri. Revista PHILIA | Filosofia, Literatura \& Arte, Porto Alegre, volume 1, número 2, p. 422 - 439, outubro de 2019. 